\title{
Can you put too much on your plate? Uncertainty exposure in servitized triads
}

\section{Kreye, Melanie E.}

Published in:

International Journal of Operations and Production Management

Link to article, DOI:

10.1108/IJOPM-06-2016-0357

Publication date:

2018

Document Version

Peer reviewed version

Link back to DTU Orbit

Citation $(A P A)$ :

Kreye, M. E. (2018). Can you put too much on your plate? Uncertainty exposure in servitized triads. International Journal of Operations and Production Management, 37(12), 1722-1740. https://doi.org/10.1108/lJOPM-06-20160357

\section{General rights}

Copyright and moral rights for the publications made accessible in the public portal are retained by the authors and/or other copyright owners and it is a condition of accessing publications that users recognise and abide by the legal requirements associated with these rights.

- Users may download and print one copy of any publication from the public portal for the purpose of private study or research.

- You may not further distribute the material or use it for any profit-making activity or commercial gain

- You may freely distribute the URL identifying the publication in the public portal

If you believe that this document breaches copyright please contact us providing details, and we will remove access to the work immediately and investigate your claim. 
Can you put too much on your plate? Uncertainty exposure in servitized triads

\author{
Melanie E. Kreye*
}

Department of Management Engineering, Technical University of Denmark

* Corresponding author

\title{
Author note:
}

Associate Professor

Address: Produktionstorvet 424, 2800 Kgs. Lyngby, Denmark

Telephone: +4545256028

Email: mkreye@dtu.dk 


\begin{abstract}
$\underline{\text { Abstract }}$
Purpose: Servitization increases the uncertainty exposure of provider firms due to the operational differences between services and production which is further increased when operations are set in triads. This paper analyses the uncertainty exposure in servitized triads and explores suitable organisational responses.
\end{abstract}

Design/methodology/approach: A conceptual frame is defined detailing three uncertainty types (environmental, organisational and relational uncertainty) and suitable organisational responses to these. This frame guided the analysis of indepth case evidence from a cross-national servitized triad in a European-North African set-up which was collected through 29 semi-structured interviews and secondary data.

Findings: The empirical study identified the existence of the three uncertainty types and directional knock-on effects between them. Specifically, environmental uncertainty created organisational uncertainty which in turn created relational uncertainty. The uncertainty types were reduced through targeted organisational responses where formal relational governance reduced environmental uncertainty, service capabilities reduced organisational uncertainty, and informal relational governance reduced relational uncertainty. The knock-on effects were reduced through organisational and relational responses.

Originality: This paper makes two contributions. First, a structured analysis of the uncertainty exposure in servitized triads is presented which shows the existence of three individual uncertainty types and the knock-on effects between them. Second, organisational responses to reduce the three uncertainty types individually and the knock-on effects between them are presented.

Keywords: servitization, engineering services, Product-service systems, case study, global operations, emerging markets, service outsourcing, offshoring 


\section{Introduction}

The trend towards specialization and outsourcing (Modi et al. 2015) means that services are increasingly provided in inter-organisational networks (Peng et al. 2010). Especially service triads where a buyer contracts a supplier to deliver a service directly to the buyer’s customer (Wynstra et al. 2015) have received research attention in recent publications. Service triads create unique organisational and operational challenges because of their typical cross-national set-up (Léo and Philippe 2001) and organisational complexity. Furthermore, an increasing number of service operations occur in the context of servitization (Vandermerwe and Rada 1988, Smith et al. 2014), where manufacturing companies strategically add services to their offerings and provide combined product-service systems (PSS) or solutions (Baines and Lightfoot 2014). Servitization creates further challenges (Brax 2005) which arise from the fundamental difference between service and manufacturing (Reim et al. 2016) including the dependence on provider and customer inputs (Sampson and Froehle 2006), inability to control quality levels (Hawkins et al. 2015) and the need for operational flexibility and heterogeneity (Kastalli and Van Looy 2013). In conjunction, servitization in a triad setup - which is referred to as servitized triads in this paper - create considerable challenges for the involved organisations.

These challenges can be conceptualised as uncertainty. Uncertainty is the lack of knowledge which arises from not definite, not known or not reliable information (Kreye et al. 2012). Different uncertainty types have been defined depending on their origin in relation to the provider. Traditional approaches differentiate between external and internal sources of uncertainty (Benedettini et al. 2015, Reim et al. 2016). External sources are typically referred to as environmental uncertainty which is defined as the unpredictability of a company’s external environment (Milliken 1987). Internal sources 
can be termed organisational uncertainty which describes the missing capabilities of an organisation (O’Connor and Rice 2013). This differentiation reflects classic organisation theory and applies to organisations such as traditional manufacturing companies. In servitized triads, relational dynamics in the long-term, business-tobusiness (B2B) relationships are additional factors that determine performance (Youngdahl et al. 2010, van der Valk and Wynstra 2012, Wynstra et al. 2015, Kreye 2016). These factors can be captured as relational uncertainty (Kreye 2017). Relational uncertainty arises because the actions of a partnering organisation cannot be predicted or explained due to lacking knowledge regarding their abilities and intentions (Kreye 2017). Uncertainty exposure in servitized triads can thus be investigated using three uncertainty types: environmental, organisational and relational uncertainty.

Current research offers little insights on the issue of uncertainty exposure in servitized triads. Service triads have received little research attention (Metters 2008a, Wynstra et al. 2015). Their role in servitization and specifically the uncertainty exposure within these set-ups has not been studied. Most of the servitization literature focuses on the provider organisation and investigate the capabilities required to incorporate services into a manufacturing company (Baines and Lightfoot 2014) to explain that servitized manufacturers face increased uncertainty exposure (Benedettini et al. 2015, Reim et al. 2016). Some authors adopt a dyad perspective to investigate the value creation in the interaction between provider and customer (Vargo 2008, Kreye et al. 2015). However, thus far no attention has been paid to servitized triads where the servitized manufacturer contracts a local supplier to provide the service directly to a customer.

This research aims to answer the following two research questions (RQ): RQ1: What uncertainty types do organisations expose themselves to in servitized triads? RQ2: 
What organisational responses to organisations engage in to reduce this uncertainty exposure in servitized triads? These questions are answered based on rich and in-depth case data of a servitized triad for a chemical production plant. The partners were situated in Europe and North Africa presenting a polar extreme for servitized triads because of the setting in an emerging market (EM) which creates particularly high levels of uncertainty (Arnold and Quelch 1998, London and Hart 2004). The findings show the existence of the three uncertainty types and depict knock-on effects between them. Further organisational responses to the individual uncertainty types and their knock-on effects are identified. This research contributes to the literature by providing a detailed analysis of the uncertainty exposure in servitized triads and suitable organisational responses.

\section{Literature review}

This section presents a literature review with regard to servitized triads, uncertainty in servitized triads and organisational responses. The literature review is summarised in a conceptual frame.

\subsection{Servitized triads}

Service triads create various organisational challenges because of the increased complexity of interactions and relationships in comparison to service dyads ( $\mathrm{Li}$ and

Choi 2009). Many service triads, where the service is delivered directly by a supplier to a buyer’s customer (Wynstra et al. 2015) involve a cross-national set-up (Léo and Philippe 2001) with operations typically set in an EM (Youngdahl et al. 2010, Größler et al. 2013). EMs pose significant challenges for international businesses (see Table 1) which arise from typically weak institutions with missing features (Acquaah 2007), inefficient judicial features (London and Hart 2004), high pace of political change 
(Hoskisson et al. 2000), and the strong influence of (local) governments and regulatory bodies (Arnold and Quelch 1998). For example, for five decades Egypt had a history of political oppression under the "emergency law" that suspended most constitutional rights and freedoms and gives government extreme powers (Youssef 2011). As a result, international organisations need to imitate institutional functions that are present in developed economies (Khanna and Palepu 1997), need to implement effective securities regulation (Khanna and Palepu 1997) and need to use local staff with the relevant language skills and local culture (Badran and Youssef-Morgan 2015).

\section{$<$ Please insert Table 1 about here $>$}

Additional challenges can arise when differences in operational traditions and present needs collide such as companies engaging in servitization (Reim et al. 2016). These companies typically seek to achieve higher profit margins, stable cash flows, increased customer demands and lock-in situations (Wise and Baumgartner 1999). The aim is to provide additional customer value by guaranteeing or improving the operation of a product (Kastalli and Van Looy 2013). This is enabled through close customer relationships (Dwyer et al. 1987, Kreye et al. 2015) which are long-term B2B arrangements (Vargo and Lusch 2008) with a strong technological focus and planned and administered transactions (Tax et al. 2013). However, many companies fail to achieve these benefits as frequently reported in the literature (Benedettini et al. 2015, Lee et al. 2016) due to the operational challenges described above. In servitized triads, the buyer may be an internationally operating servitized manufacturer who outsources part of the service arrangement to a supplier with a local service business in an EM to provide front-line service support to a local customer (Youngdahl et al. 2010, Größler et al. 2013). Thus, the level of uncertainty exposure is further increased in servitized triads (Metters 2008a, van der Valk et al. 2009, Wynstra et al. 2015) in comparison to dyads. 


\subsection{Uncertainty in servitized triads}

Uncertainty needs to be differentiated from risk; however, the literature differs in conceptualising the two terms (Knight 1921, Van der Sluijs et al. 2005, Kreye et al. 2012). Uncertainty has received contradicting definitions where some authors highlight the lack of predictability as the core characteristic (Knight 1921, Sommer and Loch 2004, Loch et al. 2008) while others highlight the lack of knowledge and thus lack of certainty about an issue (Kahneman and Tversky 1982, Pich et al. 2002). For the purpose of this research, the following definitions are used. Uncertainty is defined as a potential deficiency in any phase or activity of the process which can be characterised as not definite, not known or not reliable (Soanes 2005, Kreye et al. 2012). This means that some relevant information is not known or knowable (Brashers 2001). Risk can be defined as the possible impact or outcome of this uncertain situation or problem such as the bankruptcy of a servitized firm (Benedettini et al. 2015). This research focuses on uncertainty; a detailed analysis of risk is outside of the scope of this paper. Specifically, three uncertainty types are investigated as described above: environmental, organisational and relational uncertainty.

Environmental uncertainty is associated with changes in the external environment of organisations (Milliken 1987) and is thus fundamentally uncontrollable by them (Schmidt and Wei 2006). In servitized triads, environmental uncertainty can be particularly high due to the cross-national set-up of operations, possibly in an EM, and thus create challenges as described in Table 1. In addition, challenges arise from possible deterioration of international relations between the buyer's and customers countries that may lead to trade constraints (Metters 2008a). Environmental uncertainty may arise from foreseeable events such as variations in availability of supply (Chao et al. 2009) and unforeseeable events such as unexpected changes in the political 
relationships (Metters 2008a) or political unrests (Hoskisson et al. 2000). Thus, in servitized triads, environmental uncertainty may be particularly high due to the crossnational set-up.

Organisational uncertainty, in contrast, arises from inside an organisation (Kreye et al. 2014). Internal challenges captured in organisational uncertainty have been highlighted as the main challenge for servitized manufacturers (Benedettini et al. 2015). In service outsourcing, organisational uncertainty can arise from, for example, the lacking understanding, skills and competence of the buyer to design appropriate service level agreements (Harland et al. 2005). Furthermore, the geographical distance can pose significant operational challenges including logistics support and supply chain management (Léo and Philippe 2001). Organisational uncertainty may also arise from the cultural differences between employees in developed countries and EMs (Hofstede 2003, Metters 2008b). For example, the national culture (Hofstede 2003) of North African countries compare to European countries in terms of a lack of long-term orientation, high power distance and high level so uncertainty avoidance (see Table 2). This can create issues particularly in services which are typically characterised by longterm partnerships and high levels of individual freedom of service engineers creating situations of low power distance (Dwyer et al. 1987, Kreye 2016). In summary, organisational uncertainty may be caused by environmental uncertainty in terms of environmental instability (Milliken 1987). Thus, organisational uncertainty may be particularly high in servitized triads due to the cross-national and cross-cultural set-up.

\section{<Please insert Table 2 about here $>$}

Relational uncertainty arises from the central importance of close relationships in servitization (Vargo and Lusch 2008) and service triads (Youngdahl et al. 2010, Wynstra et al. 2015). It can arise from the dependence on the customer's diligence, 
commitment and responsibility (Léo and Philippe 2001), the customer’s changing needs (Hawkins et al. 2015) and subsequently the variation in the interaction between provider and customer (Sampson and Froehle 2006). Relational uncertainty for the service provider may thus arise as a knock-on effect from the customer’s organisational uncertainty (Kreye 2017). Specifically in service triads, the need for the design and management of interfaces and the interaction process are important considerations (van der Valk and Wynstra 2012) which depend on the relationship objectives of the three partnering organisations (Wynstra et al. 2015) and prior tie strengths (Wynstra et al. 2015). Furthermore, Acquaah (2007) pointed out that in international environments, business relationships can be difficult to evaluate because of differences in social, legal and regulatory standards between countries which can create uncertainty regarding legal protection and the possibility to solve disputes (London and Hart 2004). Specifically in EMs this is an important challenge because of the lack of judicial systems (Khanna and Palepu 1997) (see Table 1). Thus, relational uncertainty can create a particularly important challenge in servitized triads.

\subsection{Organisational responses to uncertainty in services}

The different uncertainty types require different organisational responses to reduce them and enable effective and efficient service operations.

Responding to environmental uncertainty remains a great challenge for many organisations due to the lack of control they have over developments in the external environment (Schmidt and Wei 2006). As a result, managers need to respond to environmental uncertainty after the effects on their organisation have become apparent (Milliken 1987). In service triads, the operational performance depends on the partners' abilities to adjust to developments and unexpected changes in the political, regulatory or economic environments including proactive responses (London and Hart 2004) and 
flexibility (Arias-Aranda et al. 2010). Specifically for operations in EMs, the ability to use local staff, who are strong and persistent people acquainted with unstable working conditions including most difficult situations such as wars (Badran and YoussefMorgan 2015), may enable organisations to overcome environmental uncertainty.

To respond to organisational uncertainty in servitization, organisational capabilities need to be developed and maintained to meet the needs of the specific task (Galbraith 2002). This includes service capabilities such as changes in the organisation culture towards customer focus and flexibility in operations (Kastalli and Van Looy 2013) and often requires improvements in organisational communication and coordination mechanisms (Galbraith 2002) to ensure that the relevant information for service visits is available (Kreye et al. 2015). To overcome cultural differences between employees of different origins, companies need to engage in continuous learning (Bishara 2011) that includes training of employees in relevant organisational processes and social routines to enable staff to appreciate the benefits of the existing social infrastructure in the EM (London and Hart 2004). Thus, organisational responses to organisational uncertainty in servitized triads include a broad set of capabilities including service capabilities and staff development.

To respond to relational uncertainty, suitable governance mechanisms need to be implemented (Srivastava et al. 2001) including formal and informal activities (Cousins et al. 2006). Formal governance mechanisms include prescribed routines for problemsolving (Poppo and Zenger 2002), communication guidelines and processes (Lui and Ngo 2004) which are typically included in contracts (Carey et al. 2011). However, legal protection in EMs is uncertain (London and Hart 2004) because disputes are less likely to be solved through judicial channels (Khanna and Palepu 1997). Thus, informal mechanisms including social routines and behaviour and building close personal 
relationships between employees of the different partnering organisations (Kim et al. 2015) may be more suitable responses to relational uncertainty. These informal mechanisms have been found to be particularly useful for reducing relational uncertainty in servitization (Kreye 2017). Specifically in service triads, informal mechanisms such as communication (Li and Choi 2009, Youngdahl et al. 2010) and continued direct involvement (Modi et al. 2015) are important tools of relational governance. It may thus be particularly informal governance mechanisms that are suitable responses to relational uncertainty in servitized triads.

\subsection{Conceptual frame}

This research investigates two main elements to answer the RQs: the uncertainty exposure of organisations in servitized triads and the organisational responses to this uncertainty (see Figure 1). To study the uncertainty exposure, this research focused on three uncertainty types: environmental, organisational and relational uncertainty. The aim is specifically to identify their characteristics in servitized triads. Furthermore, this research aims to identify effective organisational responses to reduce the uncertainty exposure. Specifically, the study investigates the suitability of local staff in reducing environmental uncertainty, service capabilities and staff development to reduce organisational uncertainty, and informal governance mechanisms to reduce relational uncertainty.

\section{$<$ Please insert Figure 1 about here $>$}

Furthermore, possible knock-on effects between the three uncertainty types are included in the conceptual frame. The literature has specifically described three possible knock-on effects between uncertainty types. First, environmental uncertainty can cause organisational uncertainty. For example, Milliken (1987) explained that the unpredictable state of the external environmental (state uncertainty) can cause 
uncertainty regarding the impact on the organisation (effect uncertainty) and subsequently regarding suitable organisational responses (response uncertainty). Second, environmental uncertainty can cause relational uncertainty. Authors such as Lazzarini et al. (2008) and Wynstra et al. (2015) have described the impact of environmental uncertainty on the relationship dynamics in service triads. Third, organisational uncertainty can create knock-on effects to relational uncertainty. Particularly in services, the organisational uncertainty of one service partner can create relational uncertainty for another service partner (Kreye 2017). The suitability of organisational responses may depend on the root cause of the uncertainty and hence the knock-on effects between uncertainty types (Milliken 1987, Lazzarini et al. 2008, Kreye 2017). The possible knock-on effects are thus included in the analysis and conceptual frame.

\section{Method}

To answer the RQs, an exploratory research method is applied focusing on a single case for the following reasons. First, operational considerations in servitization are contextspecific because they depend on factors such as the industry, nature and size of service portfolio (Kastalli and Van Looy 2013). Case-study research is suitable in this context because contextual factors can be included in the analysis and their effect on the findings separated (Barratt et al. 2011). Second, a case allows the identification of the empirical evidence needed to improve understanding and expand on current theory (Ketokivi and Choi 2014). This is particularly important for the research presented in this paper due to the lack of empirical and theoretical insight on uncertainty exposure in servitized triads. Third, service triads create unique organisational and operational challenges, specifically in a B2B set-up (Léo and Philippe 2001) and require further efforts of theory building through empirical investigations. Thus, the single-case 
approach was deemed suitable for the exploratory nature of this research.

\subsection{Case selection}

This paper presents insights from a servitized triad in a cross-national set-up between Europe and an emerging economy in North Africa. The case context has been anonymised to protect the companies' identities. The case set-up can be categorised as a supplier-buyer-customer triad according to the literature (Li and Choi 2009, Wynstra et al. 2015) with a European servitized manufacturer (European buyer), a North African Service provider as the supplier and a North African Customer. The engineering service concerned the operation and maintenance of a chemical production plant in North Africa. This can be characterised as advanced servitized operations with output focus (Tukker 2004). The service activities included maintenance of equipment, monitoring and intervention of the production process regarding efficiency and product quality. The link between a developed country and an EM is particularly relevant for this research (Größler et al. 2013) because it provides insights from a polar extreme in the field, hence offering guidance and new insights (Eisenhardt 1989).

\subsection{Data collection}

The empirical data included multiple sources of evidence such as semi-structured interviews, documentation notes from multiple site visits to the three companies' head offices and the plant, meetings, field notes, documentation of the organisations including the service contracts, annual reports, presentations and marketing material. A total of 29 semi-structured interviews were conducted - ten with the European buyer, twelve with the Service provider and seven with the Customer (see Table 3). The interviews varied in length between 30 and 90 minutes and were recorded and transcribed. The interviewees were selected based on their involvement in the service 
contract and engagement with the collaboration partners. Thus, the interviewees were able to give in-depth insights regarding the elements of the conceptual frame.

\section{$<$ Please insert Table 3 about here $>$}

The interviews were guided by a list of questions covering a set of issues regarding the service provision and the companies’ relationship. The discussed topics included business strategy and the global and local business environment, the contract negotiations and the relationship after contract signature. The questions did not specifically focus on uncertainty or the interviewees' uncertainty perception as this was found to bias interviewees in their discussions and thus reduce the usefulness of the gathered findings (de Bruin et al. 2002, Kreye et al. 2013). Rather it was aimed to uncover the sources of this uncertainty through the discussions. The interviews were conducted on-to-one in employees’ offices and designated meeting rooms.

\subsection{Data analysis}

The unit of analysis is the servitized triad. The data were carefully analysed through systematic, iterative coding into major thematic categories which emerged from the theoretical framing and conceptual framework (see also Figure 1) (Glaser 1992, pp. 4577). Subsequently, the data were coded based on the researchers' understanding and interpretation of the data. The final codes arose based on the empirical data by combining empirical data analysis, collection and the literature to facilitate theory building (Miles et al. 2014, pp. 292-293). The coding structure was created and refined iteratively by identifying links between the investigated concepts (Miles et al. 2014) which allowed the researchers to create a cognitive map of the case events and identify links between local incidents in the case studies. Furthermore, the case was written up as a case report and presented to the companies for verification and discussion to give 
an opportunity to comment on observations and initial conclusions. This allowed for further clarifications and refinements of the conclusions.

\section{Findings}

The case findings are outlined first with regard to the case context, the uncertainty exposure and organisational responses following the conceptual frame (Figure 1). Table 4 summarises the observations and forms the basis for the discussion.

\section{<Please insert Table 4 about here $>$}

\subsection{Case context}

The service focused on highly complex service operations with close engagement between the triad partners. The contract included various service activities:

“a) ensuring a smooth, economic and efficient operation of the Plant, b) attaining and optimizing the production and energy consumption, c) implementing and maintaining a high level of security, safety, housekeeping and environmental protection and health \& safety management systems” (Contract, p.10).

For this purpose, each plant had a specific organisation which had to be staffed with qualified personnel. The close relationship arose from the interdependent operations between provider and customer which required joint commitment:

"You will be married for at least five years so you are better really sure about this." (National manager 1, Local service provider)

Furthermore, their lack of experience in service provision area increased the uncertainty exposure for the organisations:

“This is a dangerous and risky undertaking for us. We've never done it before.”

(Vice President, European buyer) 


\subsection{Uncertainty exposure in servitized triads}

Instances of the three uncertainty types of environmental, organisational and relational uncertainty were observed.

\subsubsection{Environmental uncertainty}

Environmental uncertainty arose from the contextual setting of the service operations in North Africa. The start-up of the chemical production plant required acquaintance with the local procedures and coordination with the local authorities to obtain the relevant licenses and agreements:

\footnotetext{
“[site licenses regarding] paved roads, lighting, sewage, waste water, licenses for communication (e.g. walkie talkies) and also site security to international standard" (Contract p.19).
}

The procedures for acquiring these approvals differed from European procedures and thus caused uncertainty for the European buyer and Service provider. Furthermore, the availability of qualified staff on the national market in North Africa caused uncertainty. The education standards differed significantly to European standards which caused challenges to hire qualified service operations staff:

“[Many people in North Africa] don’t have computer access. Not all are IT literate. (...) Not everybody speaks English or can understand it at the level of [our corporate] system.” (HR Project Manager, European buyer)

Environmental uncertainty also arose from the supply of raw materials and their chemical composition which differed from the original material in the plant design. This had great implications for the production and maintenance:

"raw material supply causes very high wear and tear in the raw mill which causes very high maintenance cost.” (Quality control manager, Service provider)

Furthermore, a wave of political unrest known as the Arab Spring swept through North Africa from 2011 to 2014 and created political and economic problems for the 
servitized triad. This event was unforeseen in its scale and extent and caused shortages of gas and electricity as well as other supplies across the whole country:

"None of us had anticipated that diesel, oil, and gas could be a problem. But it is a major problem now. (...) So that means that most of the plants in North Africa are not running at full capacity.” (Head of Technical O\&M)

The political and economic instability caused major strategic and operational issues for the service provider.

\subsubsection{Organisational uncertainty}

When starting the business, the service provider quickly realised the difficulty of providing engineering services:

"The difficult part is to build the [plant] organisation [i.e. employ enough staff to operate and maintain the plant], run the organisation, and get all the CSR

[Corporate Social Responsibility] aspects of it right. That would be at least twothirds of our efforts. The technical side is like a sideshow really.” (Vice President O\&M, European buyer)

Due to the operational complexity of the studied service - O\&M support for a complete plant - substantial efforts were needed to start-up the operations:

“Each plant has a complete organisation of 200 to 300 people. There’s a plant manager and a production manager, a maintenance manager, there is a complete organisation.” (Head of O\&M Chemical, European buyer)

The organisational uncertainty was particularly high once the service agreement was signed because of the extent of activities required at this stage:

"you're not going to start building an organisation before you sign the contract."

(National manager 1, Service provider)

One particular issue was the difference between local North African employees and their attitudes towards safety in comparison to European standards, suggesting that organisational uncertainty arose also from the cultural differences between European 
tight H\&S regulations in comparison to the local habits in North Africa:

"in [Europe], everybody has to wear the goggles and you have to have safety shoes, vest and all this sort of stuff. (...) and they [in North Africa] don't do it.” (Mechanical maintenance manager, European buyer)

Furthermore, due to the Arab Spring and the resulting low availability of gas and electricity, the service partners experienced major operational challenges and disruptions:

"Most of the plants in North Africa are not running at full capacity. But when we made our business plan years ago, we thought that we will run at 100\%-110\% capacity but now we are running $75 \%$ or $80 \%$. So it's difficult just to cover the costs.” (Head of Technical O\&M, European buyer)

Thus, the external event translated into organisational uncertainty in the service triad and in turn created relational challenges with the European buyer and Customer.

\subsubsection{Relational uncertainty}

The Provider had a close relationship with the Customer:

“they tried to make us successful.” (Vice President O\&M, European buyer)

However, the events of the Arab Spring and the following reduced levels of production and operational output created relational uncertainty which initially manifested itself in the relationship between Service provider and Customer and subsequently also involved the European buyer:

"they (the Customer) have claimed force majeure.” (Performance manager, European buyer)

This situation suspended the service agreement between the partners meaning that the Service provider and European buyer received no financial compensation for the reduced production. In turn, this situation raised questions regarding the continuation of the involvement in a future service arrangement. 
Prior to the events of the Arab Spring, the service partners also experienced relational uncertainty. Once the service agreement was established, disagreements and problems arose:

"It's in the industry, safety incidences, technical breakdowns, people issues." (Head of O\&M Chemical, European buyer)

In one specific incident, a fatality happened on the plant which created a particularly difficult situation in the relationship between Customer and Service provider:

"He [the customer's CEO] saw a man falling from about 25 metres onto the ground right before his eyes.” (National manager 1, Service provider)

\subsection{Organisational responses to uncertainty}

The case companies showed specific organisational responses to the uncertainty exposure which are described with regard to the three uncertainty types.

\subsubsection{Responding to environmental uncertainty}

Much of the environmental uncertainty was regulated in the contract to be the customer's responsibility. This meant that the service provider limited their uncertainty exposure with regards to dealing with local institutes and government and concerned, for example, the customer's responsibility for dealings with the local authorities:

"[the owner is responsible for] settling of all issues relating to any Competent Authority (...and) shall obtain and renew all approvals and licenses from Competent Authority” (Contract p. 17).

To deal with the uncertainty arising from the local availability of qualified staff, the European buyer and Service provider applied an innovative approach to ensure the future availability of qualified and trained personnel:

"we initiated our own cooperation with a university, an engineering university and created [a Chemical Engineering] Institute, where we trained engineers in the last 
year of their bachelor of engineering to have chemical production knowledge.”

(General manager training, European buyer)

This approach would further reduce the induction period when hiring these staff and thus seems a sustainable solution to environmental uncertainty in EMs with regard to the availability of local staff:

"We have actually hired ten of the engineers that we had on that programme.

Thirty-three passed.” (General manager training, European buyer)

The Service provider aimed at managing the uncertainty from the supply of raw materials through developing the necessary capabilities. The service provider made a deliberate decision to reduce the environmental uncertainty by developing the necessary organisational capabilities and offering this service themselves:

“Now we're building these capabilities so that we can go to the clients say, 'We'll also run the [supply] for you.'” (Head of O\&M Chemical, European buyer)

\subsubsection{Responding to organisational uncertainty}

The Service provider learned to manage the organisational uncertainty which thus reduced over time as the service provider became more experienced with the environment in the EM and the needed service capabilities. Specifically, they established procedures for establishing plant-specific operations including hiring new employees with each new service contract:

"now we have procedures that are written down." (Head Technical O\&M, European buyer)

During the Arab Spring, it was the local employees who kept the plant running and helped respond to the organisational uncertainty:

"It came down to people being determined even though the expats had left."

(National manager 1, Service provider) 
Following the Arab Spring, the Service provider ensured corporate responsiveness in close collaboration with the customer as they took active steps to limit the vulnerability of their organisation and operations to ensure mid-term continued operations:

"we did a contingency plan how to continue operating the plant even if there would be difficulties experienced by our employees.” (National manager 1, Service provider)

\subsubsection{Responding to relational uncertainty}

Relational uncertainty was dealt with together with the customer. For example, the contingency plan on how to continue operations was executed in collaboration with the

\section{Customer:}

"As soon as I finished that meeting I called the customer. [...] And this is something that they appreciate very much.” (National Manager 1, Service provider)

Similarly, a joint approach was followed to re-establish the service arrangement between the partners:

"We had two reasons to go ahead. The first one was that we knew we were choking [the Service provider]. (...) So we showed that we would do our best to provide fuel, also to prevent future legal actions. (...) The second reason was that we were selfish about the availability and the continued production. (...) We decided to help them (the Service provider and European buyer) as we wanted them to stay” (Chief operations officer, Customer)

This statement depicts the collaborative and close involvement between the three partners. This close relationship started before the Arab Spring as regular communications were important from the beginning to establish a shared understanding about the responsibilities and processes:

"I call it building the goodwill account. (...) there is just a big difference when they know you already and they know where you're coming from and they know that 
you're a fair person. And they're more understandable and willing to accept some of your mistakes if there is that goodwill account." (National manager 1, Service provider)

Thus, a close relationship helped in this case to overcome the relational uncertainty that was caused by the external event of the Arab Spring.

\section{Discussion and conclusions}

This section discusses the findings with regard to uncertainty exposure in servitized triads and organisational responses based on the two RQs (see also Figure 1).

\subsection{Theoretical contribution}

This research aimed to investigate two research questions: RQ1: What uncertainty types do organisations expose themselves to in servitized triads? RQ2: What organisational responses to organisations engage in to reduce this uncertainty exposure in servitized triads? The presented study findings indicate exposure to the three uncertainty types identified in the conceptual frame (Figure 1): environmental, organisational and relational uncertainty. The findings also showed directional knock-on effects between these uncertainty types. Furthermore, the study revealed organisational responses to the uncertainty exposure by targeting the individual effects of the three observed uncertainty types as well as the knock-on effect between them. These insights contribute to the service triad literature by presenting a detailed analysis of the uncertainty exposure in servitized triads and identifying organisational responses to the uncertainty exposure. This supports the notion in the servitization literature of increased uncertainty exposure through empirical evidence.

\subsubsection{Uncertainty exposure in servitized triads}

The three uncertainty types had distinct sources and impacted the operations in the 
servitized triad differently. Environmental uncertainty was created during the start-up period-exemplified through a need to get acquainted with local procedures and the availability of qualified staff - and during the operations period of the servitized triad exemplified through supply uncertainty and political unrests. Environmental uncertainty was further found to be heterogeneous as it arose from both regular occurring and thus foreseen events - such as the variations in the amount and quality of supplied raw materials - and unforeseen events - for example the Arab Spring. This confirms expectations from the literature regarding the high environmental uncertainty caused in servitized triads which include a cross-national set-up in an EM as indicated in Table 1.

The case observations for organisational uncertainty showed two specific sources. First, the operational complexity of the performance-based contract manifested itself particularly once the PSS agreement had been signed. At that point, the provider needed to employ the relevant staff and organise the operations. This created uncertainty because the timing and scale of the operations could not be precisely predicted prior to finalising the contract. Thus, the organisational uncertainty arose here from the operational complexity of the PSS arrangement in the service triad. Second, organisational uncertainty arose from the cultural differences in work attitudes between European and North African engineering staff. This observation arose from the crossnational set-up and the resulting differences in national cultures (Hofstede 2003). Our findings emphasise that these cultural differences create organisational uncertainty in the servitized triad.

The case observations showed low levels of relational uncertainty between the service partners because of their close and collaborative relationship despite the lack of prior engagement. This contrasts descriptions in the literature describing that a lack of prior engagement limits the amount of trust (Bastl et al. 2012) and hence increases 
relational uncertainty especially in cross-national set-ups involving EMs (London and Hart 2004). The findings may link to the literature on manufacturing triads which have been found to offer greater perception of stability (Mena et al. 2013). The findings suggest that this observation could also apply to servitized triads. Thus, the triad set-up increased the partners' perception of stability and hence reduced the relational uncertainty.

Further knock-on effects between the three uncertainty types were observed showing specifically that relational uncertainty was created as a knock-on effect from organisational and environmental uncertainty. For example, the disruptions caused by the Arab Spring (environmental uncertainty) caused operational disruptions (organisational uncertainty) which in turn created a disruption to the service arrangement between the partners (relational uncertainty). Similarly, the lack of North African staff to follow European health and safety standards (organisational uncertainty) caused a deadly accident in front of the Customer's CEO which created challenges in the collaboration (relational uncertainty). Figure 2 depicts these observations.

\section{$<$ Please insert Figure 2 about here $>$}

The findings thus confirmed two of the three possible knock-on effects between uncertainty types suggested by the literature: from environmental to organisational uncertainty, and from organisational uncertainty to relational uncertainty. The knock-on effects from environmental to relational uncertainty as suggested by authors such as Lazzarini et al. (2008) and Wynstra et al. (2015) were only observed indirectly via organisational uncertainty. This suggests a causal hierarchy amongst uncertainty types as environmental uncertainty caused organisational and subsequently relational 
uncertainty. Thus, the combination of uncertainty types increases the overall uncertainty exposure in servitized triads due to knock-on effects.

\subsubsection{Organisational responses to uncertainty exposure}

The second contribution of this research is the identification of organisational responses to the individual uncertainty types and the knock-on effects between them. To respond to environmental uncertainty, the Service provider utilised the service contract which deflected responsibility to the customer. This concerned particularly environmental uncertainty regarding foreseen events such as the supply of raw materials and the coordination with local authorities. This is a novel finding as current literature has linked these mechanisms to relational concerns (Poppo and Zenger 2002, Lui and Ngo 2004). In contrast, this study’s observations link formal relational governance mechanisms such as service contracts to environmental uncertainty and describe them as useful tools to manage uncertainty in the external environment by assigning the responsibility to the triad part which is has most experience in dealing with it. This research thus expands the literature by showing the suitability of formal governance mechanisms for managing specifically environmental uncertainty.

To reduce organisational uncertainty, the Service provider utilised relevant service capabilities such as establishing service procedures and managing staff skills. This emphasises the role of service capabilities in servitization (Kastalli and Van Looy 2013, Baines and Lightfoot 2014) which benefit a service provider in reducing their organisational uncertainty. Furthermore, the findings showed that training activities reduced the organisational uncertainty arising from the cultural differences between employees with regard to, for example, health and safety standards. This confirms expectations from the literature that highlight employee training as an important organisational tool to enable staff to benefit from existing organisational structures and 
procedures (London and Hart 2004, Bishara 2011). These findings link these observations to the concept of organisational uncertainty in servitized triads and demonstrate their usefulness in reducing this uncertainty.

The low levels of relational uncertainty were created through the close relationship between the European buyer and the supplier (Service provider). In addition, the service partners actively ensured a close relationship through informal governance mechanisms such as informal communication channels (Kreye et al. 2015) and social routines (Dyer and Singh 1998). Thus, this research suggests that the perception of increased relationship stability creates incentives for the partners to ensure this stability through joint actions.

The findings further showed organisational responses to the knock-on effects between uncertainty types, specifically through organisational and relational activities. For example, the Service provider used their capability for responsiveness in decision making to resolve the organisational uncertainty arising from the disruptions caused by the Arab Spring. This contrasts descriptions in the literature that link responsiveness directly to environmental uncertainty (London and Hart 2004) and shows that it is the knock-on effects of environmental uncertainty to organisational uncertainty that are managed through suitable organisational capabilities of flexibility and responsiveness. Furthermore, the Customer was involved closely in these activities to reduce the connected relational uncertainty. This also suggests that it is the knock-on effects of environmental and organisational uncertainty that are managed through relational capabilities. Thus, the environmental uncertainty arising from the unforeseen event of the Arab Spring was resolved indirectly through managing the knock-on effects to organisational and relational uncertainty. This research thus gives causal explanations 
for the organisational responses to environmental uncertainty through organisational and relational responses.

\subsection{Managerial implications}

This research offers novel managerial insights for managers in service operations and triad set-ups in EMs. First, the nature of the uncertainty exposure is manifold with various uncertainty types influencing the service operations and continuation of these operations in servitized triads. Managers need to be aware of this heterogeneous nature of uncertainty exposure to ensure service performance. Second, each of these uncertainty types need distinct organisational responses to successfully reduce and manage their impact on the operations. Managers need to respond to their company's exposure to environmental uncertainty through formal governance tools. This enables responding to uncertain events such as supply disruptions or variations, and demand uncertainty. Specifically, tools such as service contracts can be used to direct the responsibility of managing the uncertainty to the party with the highest ability and possibility of managing it. Managers further need to place high importance responding to the organisational uncertainty in the servitized triad. Failing to address this organisational uncertainty can create knock-on effects and thus increase the overall uncertainty exposure in the servitized triad. Finally, managers are advised to address their relational uncertainty in servitized triads through informal relational governance mechanisms. Specifically, building close personal ties and regular communications with the service partners was found to be a suitable response to relational uncertainty which also enabled them to manage the knock-on effects from organisational and environmental uncertainty by jointly addressing challenges as they arise. 


\subsection{Limitations and future research}

The limitations arise from the qualitative methodology of this research. Case study research has been linked to observer bias and subjectivity in data analysis (Yin 2009). These limitations were mitigated by data triangulation between interview data and secondary data to improve the reliability (Yin 2009). Furthermore, the results focus on the empirical context of a chemical production plant with a triad set-up between Europe and North Africa. The presented research thus applies a contingency approach that highlights the dependency on research and business contexts (Barratt et al. 2011).

Future research can build on the presented findings and limitations. Specifically, the following three pathways for future research can be identified. First, the knock-on effects between uncertainty types need further research attention. This research offered a first qualitative observation of these knock-on effects suggesting a causal relationship between environmental, organisational and relational uncertainty. Replicating these insights in other settings including cross-national servitized triads and intra-national setups in, for example, service dyads would further enhance understanding of these effects. Second, organisational responses to the different uncertainty types deserve further research attention. This research pointed towards different responses to the three uncertainty types. Further work is needed to provide further insights on the effectiveness of these responses in reducing uncertainty. Specifically, further case studies can elaborate on these insights and provide a suitable basis to further theory building in this area. Third, organisational responses to managing the knock-on effects between uncertainty types require further research attention. This research suggests that it is particularly the organisational and relational responses that enable companies to manage these knock-on effects, yet further work is required to identify the possibility of preventing knock-on effects by targeting their root cause. Identifying activities to 
prevent knock-on effects between uncertainty types would further theory-building in the field.

\section{References}

Acquaah, M., 2007. Managerial social capital, strategic orientation, and organizational performance in an emerging economy. Strategic Management Journal, 28 (12), $1235-1255$.

Arias-Aranda, D., Bustinza, O. F., and Barrales-Molina, V., 2010. Operations flexibility and outsourcing benefits: an empirical study in service firms. The Service Industries Journal, 31 (11), 1849-1870.

Arnold, D. J. and Quelch, J. A., 1998. New Strategies in Emerging Markets. Sloan Management Review, 40 (1), 7-20.

Badran, M. A. and Youssef-Morgan, C. M., 2015. Psychological capital and job satisfaction in Egypt. Journal of Managerial Psychology, 30 (3), 354-370.

Baines, T. and Lightfoot, H. W., 2014. Servitization of the manufacturing firm: Exploring the operations practices and technologies that deliver advanced services. International Journal of Operations \& Production Management, 34 (1), 2-35.

Barratt, M., Choi, T. Y., and Li, M., 2011. Qualitative case studies in operations management: Trends, research outcomes, and future research implications. Journal of Operations Management, 29 (4), 329-342.

Bastl, M., Johnson, M., Lightfoot, H., and Evans, S., 2012. Buyer-supplier relationships in a servitized environment: An examination with Cannon and Perreault's framework. International Journal of Operations \& Production Management, 32 
(6), 650-675.

Benedettini, O., Neely, A., and Swink, M., 2015. Why do servitized firms fail? A riskbased explanation. International Journal of Operations \& Production Management, 35 (6), 946-979.

Bishara, N. D., 2011. Governance and Corruption Constraints in the Middle East: Overcoming the Business Ethics Glass Ceiling. American Business Law Journal, 48 (2), 227-283.

Brashers, D. E., 2001. Communication and Uncertainty Management. Journal of Communication, 51 (3), 477-497.

Brax, S., 2005. A manufacturer becoming service provider - challenges and a paradox. Managing Service Quality, 15 (2), 142-155.

de Bruin, W. B., Fischbeck, P. S., Stiber, N. A., and Fischhoff, B., 2002. What Number is 'Fifty-Fifty’?: Redistributing Excessive 50\% Responses in Elicited Probabilities. Risk Analysis: An International Journal, 22 (4), 713-723.

Carey, S., Lawson, B., and Krause, D. R., 2011. Social capital configuration, legal bonds and performance in buyer-supplier relationships. Journal of Operations Management, 29, 277-288.

Chao, X., Chen, H., and Zheng, S., 2009. Dynamic Capacity Expansion for a Service Firm with Capacity Deterioration and Supply Uncertainty. Operations Research, 57 (1), 82-93.

Cousins, P. D., Handfield, R. B., Lawson, B., and Petersen, K. J., 2006. Creating supply chain relational capital: The impact of formal and informal socialization processes. 
Journal of Operations Management, 24 (6), 851-863.

Dwyer, F. R., Schurr, P. H., and Oh, S., 1987. Developing Buyer-Seller Relationships. Journal of Marketing, 51 (2), 11-27.

Dyer, J. H. and Singh, H., 1998. The Relational View: Cooperative Strategy and Sources of Interorganizational Competitive Advantage. The Academy of Management Review, 23 (4), 660-679.

Eisenhardt, K. M., 1989. Building theories from case study research. Academy of Management Review, 14 (4), 532-550.

Galbraith, J. R., 2002. Organizing to Deliver Solutions. Organizational Dynamics, 31 (2), 194-207.

Glaser, B. G., 1992. Basics of grounded theory analysis. Mill Valley, CA: Sociological Press.

Größler, A., Timenes Laugen, B., Arkader, R., and Fleury, A., 2013. Differences in outsourcing strategies between firms in emerging and in developed markets. International Journal of Operations \& Production Management, 33 (3), 296-321.

Harland, C., Knight, L., Lamming, R., and Walker, H., 2005. Outsourcing: assessing the risks and benefits for organisations, sectors and nations. International Journal of Operations \& Production Management, 25 (9), 831-850.

Hawkins, T. G., Gravier, M. J., Berkowitz, D., and Muir, W. A., 2015. Improving services supply management in the defense sector: How the procurement process affects B2B service quality. Journal of Purchasing and Supply Management, 21 (2), 81-94. 
Hofstede, G. H., 2003. Cultures consequences: Comparing values, behaviors, institutions and organizations across nations. 2nd ed. Thousand Oaks, CA, USA: Sage Publications.

Hoskisson, R. E., Eden, L., Lau, C. M., and Wright, M., 2000. Strategy in emerging economies. Academy of Management Journal, 43 (3), 249-267.

Kahneman, D. and Tversky, A., 1982. Variants of uncertainty. Cognition, 11 (2), 143157.

Kastalli, I. V. and Van Looy, B., 2013. Servitization: Disentangling the impact of service business model innovation on manufacturing firm performance. Journal of Operations Management, 31 (4), 169-180.

Ketokivi, M. and Choi, T., 2014. Renaissance of case research as a scientific method. Journal of Operations Management, 32 (5), 232-240.

Khanna, T. and Palepu, K., 1997. Why Focused Strategies May Be Wrong for Emerging Markets. Harvard Business Review, 75 (4), 41-51.

Kim, Y., Choi, T. Y., and Skilton, P. F., 2015. Buyer-supplier embeddedness and patterns of innovation. International Journal of Operations \& Production Management, 35 (3), 318-345.

Knight, F., 1921. Risk, Uncertainty and Profit. New York, USA: Harper Torchbooks.

Kreye, M. E., 2016. Employee motivation in Product-Service-System providers. Production Planning \& Control, 27 (15), 1-11.

Kreye, M. E., 2017. Relational uncertainty in service dyads. International Journal of 
Operations \& Production Management, 37 (3), 363-381.

Kreye, M. E., Goh, Y. M., Newnes, L. B., and Goodwin, P., 2012. Approaches of Displaying Information to Assist Decisions under Uncertainty. Omega International Journal of Management Science, 40 (6), 682-692.

Kreye, M. E., Newnes, L. B., and Goh, Y. M., 2013. Information availability at the competitive bidding stage for service. Journal of Manufacturing Technology Management, 24 (7), 976-997.

Kreye, M. E., Newnes, L. B., and Goh, Y. M., 2014. Uncertainty in competitive bidding - a framework for product - service systems. Production Planning \& Control, 25 (6), 462-477.

Kreye, M. E., Roehrich, J. K., and Lewis, M. A., 2015. Servitising manufacturers: the impact of service complexity and contractual and relational capabilities. Production Planning \& Control, 26 (14), 1233-1246.

Lazzarini, S. G., Claro, D. P., and Mesquita, L. F., 2008. Buyer-Supplier and SupplierSupplier Alliances: Do They Reinforce or Undermine One Another? Journal of Management Studies, 45 (3), 561-584.

Lee, S., Yoo, S., and Kim, D., 2016. When is servitization a profitable competitive strategy? International Journal of Production Economics, 173, 43-53.

Leigh, L., 2011. Breaking down corporate secrecy in the Middle East: lessons from a successful ‘infomediary’. European Business Review, 23 (2), 154-166.

Léo, P.-Y. and Philippe, J., 2001. Offer of Services by Goods Exporters: Strategic and Marketing Dimensions. The Service Industries Journal, 21 (2), 91-116. 
Li, M. E. I. and Choi, T. Y., 2009. Triads in Services Outsourcing: Bridge, Bridge Decay and Bridge Transfer. Journal of Supply Chain Management, 45 (3), 27-39.

Loch, C. H., Solt, M. E., and Bailey, E. M., 2008. Diagnosing Unforeseeable Uncertainty in a New Venture. Journal of Product Innovation Management, 25 (1), 28-46.

London, T. and Hart, S. L., 2004. Reinventing Strategies for Emerging Markets: Beyond the Transnational Model. Journal of International Business Studies, 35 (5), 350-370.

Lui, S. S. and Ngo, H.-Y., 2004. The role of trust and contractual safeguards on cooperation in non-equity alliances. Journal of Management, 30 (4), 471-485.

Mena, C., Humphries, A., and Choi, T. Y., 2013. Toward a theory of multi-tier supply chain management. Journal of Supply Chain Management, 49, 58-77.

Metters, R., 2008a. A typology of offshoring and outsourcing in electronically transmitted services. Journal of Operations Management, 26 (2), 198-211.

Metters, R., 2008b. A case study of national culture and offshoring services. International Journal of Operations \& Production Management, 28 (8), 727-747.

Miles, M. B., Huberman, A. M., and Saldaña, J., 2014. Qualitative Data Analysis: A Methods Sourcebook. 3rd ed. Thousand Oaks, CA, USA: Sage Publications, Inc.

Milliken, F. J., 1987. Three types of perceived uncertainty about the environment: State, effect, and response uncertainty. Academy of Management Review, 12 (1), 133143. 
Modi, S. B., Wiles, M. A., and Mishra, S., 2015. Shareholder value implications of service failures in triads: The case of customer information security breaches. Journal of Operations Management, 35, 21-39.

O’Connor, G. C. and Rice, M. P., 2013. A Comprehensive Model of Uncertainty Associated with Radical Innovation. Journal of Product Innovation Management, 30, 2-18.

Peng, T. A., Lin, N., Martinez, V., and Yu, C. J., 2010. Managing triads in a military avionics service maintenance network in Taiwan. International Journal of Operations \& Production Management, 30 (4), 398-422.

Pich, M. T., Loch, C. H., and De Meyer, A., 2002. On Uncertainty, Ambiguity, and Complexity in Project Management. Management Science, 48 (8), 1008-1023.

Poppo, L. and Zenger, T., 2002. Do formal contracts and relational governance function as substitutes or complements? Strategic Management Journal, 23 (8), 707-725.

Reim, W., Parida, V., and Sjödin, D. R., 2016. Risk management for product-service system operation. International Journal of Operations \& Production Management, 36 (6), 665-686.

Sampson, S. E. and Froehle, C. M., 2006. Foundations and Implications of a Proposed Unified Services Theory. Production \& Operations Management, 15 (2), 329-343.

Schmidt, M. R. and Wei, W., 2006. Loss of Agro-Biodiversity, Uncertainty, and Perceived Control: A Comparative Risk Perception Study in Austria and China. Risk Analysis: An International Journal, 26 (2), 455-470.

Sheth, J. N., 2011. Impact of Emerging Markets on Marketing: Rethinking Existing 
Perspectives and Practices. Journal of Marketing, 75 (4), 166-182.

Van der Sluijs, J. P., Craye, M., Funtowicz, S., Kloprogge, P., Ravetz, J., and Risbey, J., 2005. Combining Quantitative and Qualitative Measures of Uncertainty in ModelBased Environmental Assessment: The NUSAP System. Risk Analysis: An International Journal, 25 (2), 481-492.

Smith, L., Maull, R., and Ng, I. C. L., 2014. Servitization and operations management: a service dominant-logic approach. International Journal of Operations \& Production Management, 34 (2), 242-269.

Soanes, C., 2005. The Oxford English Dictionary. Oxford, UK: Oxford University Press.

Sommer, S. C. and Loch, C. H., 2004. Selectionism and Learning in Projects with Complexity and Unforeseeable Uncertainty. Management Science, 50 (10), 13341347.

Srivastava, R. K., Fahey, L., and Christensen, H. K., 2001. The resource-based view and marketing: The role of market-based assets in gaining competitive advantage. Journal of Management, 27 (6), 777-802.

Tax, S. S., McCutcheon, D., and Wilkinson, I. F., 2013. The Service Delivery Network (SDN): A Customer-Centric Perspective of the Customer Journey. Journal of Service Research, 16 (4), 454-470.

Tukker, A., 2004. Eight types of Product-Service System; eight ways to suistainability? Experiences from SUSPRONET. Business Strategy and the Environment, 13, 246260. 
van der Valk, W. and Wynstra, F., 2012. Buyer-supplier interaction in business-tobusiness services: A typology test using case research. Journal of Purchasing and Supply Management, 18 (3), 137-147.

van der Valk, W., Wynstra, F., and Axelsson, B., 2009. Effective buyer-supplier interaction patterns in ongoing service exchange. International Journal of Operations \& Production Management, 29 (8), 807-833.

Vandermerwe, S. and Rada, J., 1988. Servitization of Business: Adding Value by Adding Services. European Management Journal, 6 (4), 314-324.

Vargo, S. L., 2008. Customer integration and value creation: paradigmatic traps and perspectives. Journal of Service Research, 11 (2), 211-215.

Vargo, S. L. and Lusch, R. F., 2008. Service-dominant Logic: Continuing the Evolution. Journal of the Academy of Marketing Science, 36 (1), 1-10.

Wise, R. and Baumgartner, P., 1999. Go Downstream: The New Profit Imperative in Manufacturing. Harvard Business Review, 77 (5), 133-141.

Wynstra, F., Spring, M., and Schoenherr, T., 2015. Service triads: A research agenda for buyer-supplier-customer triads in business services. Journal of Operations Management, 35, 1-20.

Yin, R. K., 2009. Case study research: design and methods. Los Angeles, CA, USA: SAGE Publications.

Youngdahl, W. E., Ramaswamy, K., and Dash, K. C., 2010. Service offshoring: the evolution of offshore operations. International Journal of Operations \& Production Management, 30 (8), 798-820. 
Youssef, C. M., 2011. Recent events in Egypt and the Middle East: Background, direct observations and a positive analysis. Organizational Dynamics, 40 (3), 222-234. 


\section{Tables and Figures}

Table 1: Challenges that emerging markets (EMs) provide for Western organisations

\begin{tabular}{|l|l|}
\hline Conditions in EMs & $\begin{array}{l}\text { Operational challenges for international } \\
\text { businesses }\end{array}$ \\
\hline $\begin{array}{l}\text { Weak institutions for economic exchange } \\
\text { (Arnold and Quelch 1998, Acquaah 2007) with } \\
\text { missing institutional features }\end{array}$ & $\begin{array}{l}\text { Need to imitate functions of several institutions } \\
\text { (Khanna and Palepu 1997) } \\
\text { shortage of resources such as power supply and } \\
\text { raw material supply (Sheth 2011) } \\
\text { Lack of skill-based labour (Badran and Youssef- } \\
\text { Morgan 2015) }\end{array}$ \\
\hline $\begin{array}{l}\text { Inefficient judicial system (Acquaah 2007) } \\
\begin{array}{l}\text { Existence of bribery and corruption (Hoskisson et } \\
\text { al. 2000) }\end{array}\end{array}$ & $\begin{array}{l}\text { Uncertainty in legal protection for organisations } \\
\text { (Khanna and Palepu 1997, London and Hart 2004) }\end{array}$ \\
\hline $\begin{array}{l}\text { High pace of political change (Hoskisson et al. } \\
\text { 2000) due to political and economic instability } \\
\text { (Arnold and Quelch 1998, Hoskisson et al. 2000) }\end{array}$ & $\begin{array}{l}\text { Propensity to change of business regulations } \\
\text { frequently and unpredictably (Khanna and Palepu } \\
\text { 1997) }\end{array}$ \\
\hline $\begin{array}{l}\text { Highly influential governments and regulatory } \\
\text { bodies (Arnold and Quelch 1998, Sheth 2011) } \\
\text { "Byzantine" traditions: secretive and arbitrary } \\
\text { bureaucracy with inadequate and misleading } \\
\text { corporate disclosures (Leigh 2011) }\end{array}$ & $\begin{array}{l}\text { Difficulty of market entry for international } \\
\text { organisations (Sheth 2011) } \\
\text { Unfamiliar operational and organisational } \\
\text { conditions (Arnold and Quelch 1998) }\end{array}$ \\
\hline
\end{tabular}

Table 2: Comparison of national cultures between North African countries and European countries according to Hofstede (2003)

\begin{tabular}{|l||l|l|l||l|l|l|}
\hline & Egypt & Libya & Morocco & UK & Germany & Denmark \\
\hline \hline Power distance & 70 & 80 & 70 & 35 & 35 & 18 \\
\hline Individualism & 25 & 38 & 46 & 89 & 67 & 74 \\
\hline $\begin{array}{l}\text { Career } \\
\text { orientation } \\
\text { (masculinity) }\end{array}$ & 45 & 52 & 53 & 66 & 66 & 16 \\
\hline $\begin{array}{l}\text { Uncertainty } \\
\text { avoidance }\end{array}$ & 80 & 68 & 68 & 35 & 65 & 23 \\
\hline $\begin{array}{l}\text { Long-term } \\
\text { orientation }\end{array}$ & 7 & 23 & 14 & 51 & 83 & 35 \\
\hline Indulgence & 4 & 34 & 25 & 69 & 40 & 70 \\
\hline
\end{tabular}


Table 3: Case set-up and interviewees

\begin{tabular}{|l|l|l|l|}
\hline & European buyer & (Local) Service provider & Customer \\
\hline $\begin{array}{l}\text { Role in the } \\
\text { servitized } \\
\text { triad (Li and } \\
\text { Choi 2009) }\end{array}$ & $\begin{array}{l}\text { Servitized manufacturer } \\
\text { and provider of back-office } \\
\text { services, } \\
\text { Buyer of service operations }\end{array}$ & $\begin{array}{l}\text { Provider of front-line } \\
\text { services in North Africa, } \\
\text { Supplier of service } \\
\text { operations }\end{array}$ & $\begin{array}{l}\text { North African producer of } \\
\text { chemical products, } \\
\text { Customer of service } \\
\text { operations }\end{array}$ \\
\hline Interviewees & Vice President O\&M & National manager 1 & Chief operation officer \\
& Head O\&M Chemical & National manager 2 & Plant manager \\
& General manager O\&M & Operations director & Technical director \\
& Sales & Operations manager & Production \& process \\
& Head O\&M Technical & Quality control manager & manager \\
& Performance manager & General maintenance & Maintenance manager \\
& Procurement manager & manager & Quality control manager \\
& General manager training & Material manager & HSE manager \\
& Mechanical maintenance & Training manager & \\
& manager & Regional finance manager & \\
& Team leader HR & Financial controller & \\
& HR project manager & Head quality control & \\
& & HSE manager & \\
& &
\end{tabular}


Table 4: Summary of case findings regarding uncertainty exposure and organisational capabilities

\begin{tabular}{|c|c|c|}
\hline $\begin{array}{l}\text { Uncertainty } \\
\text { exposure }\end{array}$ & Case examples & Organisational responses \\
\hline \multirow[t]{4}{*}{$\begin{array}{l}\text { Environmental } \\
\text { uncertainty }\end{array}$} & $\begin{array}{l}\text { Acquaintance with local procedures } \\
\text { and coordination with local } \\
\text { authorities, relevant for European } \\
\text { buyer and Service provider }\end{array}$ & $\begin{array}{l}\text { Assigning the contractual obligation of } \\
\text { liaising with local authorities to the customer }\end{array}$ \\
\hline & $\begin{array}{l}\text { Availability of qualified staff on the } \\
\text { host market, relevant for Service } \\
\text { provider }\end{array}$ & $\begin{array}{l}\text { Partnering with local university to educate } \\
\text { engineering students and ensure future } \\
\text { availability of qualified staff }\end{array}$ \\
\hline & $\begin{array}{l}\text { Supply of raw materials in required } \\
\text { quantity and quality, relevant for } \\
\text { Service provider }\end{array}$ & $\begin{array}{l}\text { Developing in-house capabilities to fulfil } \\
\text { supply-related functions }\end{array}$ \\
\hline & $\begin{array}{l}\text { Political unrests of the Arab Spring } \\
\text { with unforeseen impact creating } \\
\text { political and economic instability }\end{array}$ & Not resolved directly \\
\hline \multirow[t]{2}{*}{$\begin{array}{l}\text { Organisational } \\
\text { uncertainty }\end{array}$} & $\begin{array}{l}\text { Hire qualified staff once service } \\
\text { agreement is signed, relevant for } \\
\text { Service provider }\end{array}$ & $\begin{array}{l}\text { Uncertainty reduced over time as procedures } \\
\text { were developed and implemented }\end{array}$ \\
\hline & $\begin{array}{l}\text { Cultural differences between } \\
\text { European and North African } \\
\text { employees towards working attitudes } \\
\text { such as health and safety, relevant for } \\
\text { Service provider and European buyer }\end{array}$ & $\begin{array}{l}\text { HR activities and continuous staff } \\
\text { development and training }\end{array}$ \\
\hline \multirow[t]{2}{*}{$\begin{array}{l}\text { Relational } \\
\text { uncertainty }\end{array}$} & $\begin{array}{l}\text { Discontinuation of the contractual } \\
\text { relationship due to the operational } \\
\text { disruptions caused by the Arab } \\
\text { Spring, relevant for triad }\end{array}$ & $\begin{array}{l}\text { Close collaboration between Service provider } \\
\text { and Customer with involvement of the } \\
\text { European buyer to re-establish the service } \\
\text { agreement }\end{array}$ \\
\hline & $\begin{array}{l}\text { Relational challenges from fatal } \\
\text { accident between Service provider } \\
\text { and Customer }\end{array}$ & $\begin{array}{l}\text { Building and maintaining a "goodwill } \\
\text { account” between Service provider and } \\
\text { Customer }\end{array}$ \\
\hline
\end{tabular}

